\title{
Reply to the letter to the editor by Rueda-Franco F. et al. with regard to the paper "The clinical spectrum of Blake's pouch cyst: report of six illustrative cases"
}

\author{
Erwin M. J. Cornips • Geke M. Overvliet • \\ Johannes S. H. Vles • Marcella M. L. L. Baldewijns
}

Received: 21 September 2010 / Accepted: 23 September 2010 /Published online: 12 October 2010

(C) The Author(s) 2010. This article is published with open access at Springerlink.com

\section{Dear Editor,}

We thank Rueda-Franco et al. for their interest in our paper [1]. They suggest the yellowish material covering the occipital lobes as well as the cerebellum may point to a purulent process rather than a massive cerebral necrosis. Indeed, we agree Fig. 1d in the original paper may suggest a thin layer of pus covering the brain; however, this certainly was not the case as we will now explain. The clinical presentation and laboratory findings did not point to an infection. The boy had no fever on admission nor in the days immediately before and after admission until his death 14 days postoperatively. Blood leukocyte count and C-reactive protein were within normal range, and routine cerebrospinal fluid cultures were negative. Moreover, postmortem macroscopic and microscopic examination of the child's meninges, cerebral and cerebellar cortex pointed to a massive necrosis (ischemic encephalopathy) as a result of prolonged, dramatically elevated intracranial pressure, the clinical symptoms and signs of which were very clear when the child was transferred to our hospital [1]. As such, the yellowish aspect of the surface of both brain and cerebellum corresponded to an ischemic liquefaction and

E. M. J. Cornips $(\bowtie) \cdot$ G. M. Overvliet $\cdot$ J. S. H. Vles $\cdot$

M. M. L. L. Baldewijns

Maastricht University Hospital,

P.O. Box 5800,

6202 AZ Maastricht, The Netherlands

e-mail: e.cornips@mumc.nl

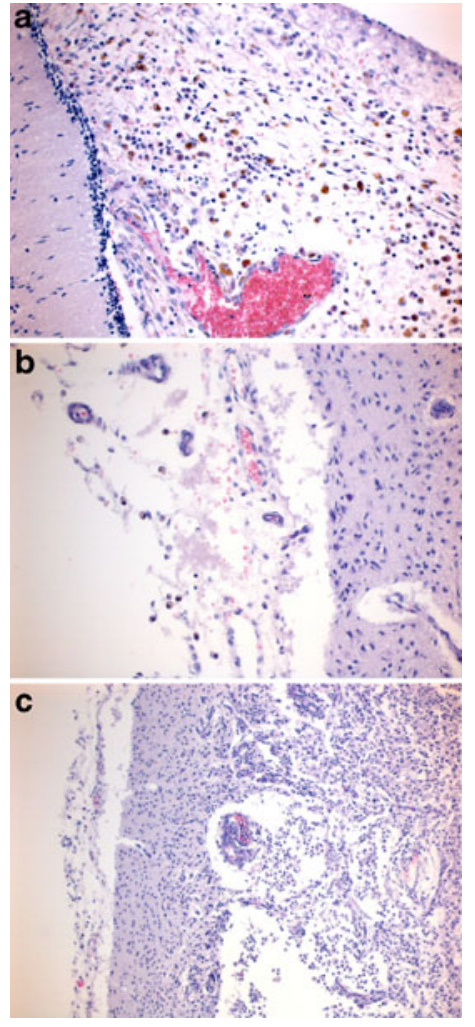

Fig. 1 a Microscopic view of cerebellar meninges. Note that there are few neutrophilic granulocytes, few lymphocytes, and many iron-loaded macrophages. b Microscopic view of cerebral meninges. Again, note the absence of a purulent infiltrate. c Microscopic view of cerebral meninges and cerebrum, clearly demonstrating an ischemic encephalopathy 
infiltration with sporadic neutrophilic granulocytes, sporadic lymphocytes, and numerous iron-loaded macrophages, as illustrated in Fig. 1a-c. This is to be regarded as a reactive process after dramatic intracranial hypertension and secondary hypoperfusion, aggravated by a suboptimal coagulation status resulting in widespread microhemorrhage.

Open Access This article is distributed under the terms of the Creative Commons Attribution Noncommercial License which permits any noncommercial use, distribution, and reproduction in any medium, provided the original author(s) and source are credited.

\section{Reference}

1. Cornips EMJ, Overvliet GM, Weber JW, Postma AA, Hoeberigs CM, Baldewijns MMLL et al (2010) The clinical spectrum of Blake's pouch cyst: report of six illustrative cases. Child's Nerv Syst 26(8):1057-1064, Epub 2010 Mar 3 